\title{
Viral hepatitis in the Canadian Inuit and First Nations populations
}

\author{
Gerald Y Minuk MD FRCPC, J Uhanova MD PhD
}

GY Minuk, J Uhanova. Viral hepatitis in the Canadian Inuit and First Nations populations. Can J Gastroenterol 2003;17(12):707-712.

OBJECTIVE: To review published prevalence data regarding hepatitis A (HAV), B (HBV) and C (HCV) in Canadian Inuit and First Nations populations.

METHODS: PubMed database search and review of all papers describing data derived from seroepidemiological surveys.

RESULTS: The prevalence of anti-HAV positivity in Canadian Inuit and First Nations populations reported to date is high (range $75 \%$ to $95 \%$ ) and approximately three times that of non-Aboriginal Canadians residing in the same communities. Among the Canadian Inuit, the prevalence of $\mathrm{HBV}$ infection is approximately $5 \%$, or 20 times that of non-Aboriginal Canadians, while the risk of exposure to $\mathrm{HBV}$ is $25 \%$, or five times higher. Regarding the First Nations population, preliminary data suggest the prevalences of $\mathrm{HBV}$ infection $(0.3 \%$ to $3 \%)$ and exposure ( $10 \%$ to $22 \%)$ are similar to rates in nonAboriginals residing in the same regions and participating in similar high risk activities. Serological evidence of HCV infection (anti$\mathrm{HCV})$ is more common in the Canadian Inuit and First Nations (1\% to $18 \%$ ) than the remainder of the Canadian population ( $0.5 \%$ to $2 \%$ ); however, viremia (HCV-RNA positivity) is less common (less than $5 \%$ versus $75 \%$ of anti-HCV positive individuals, respectively).

CONCLUSIONS: Viral hepatitis is common in the Canadian Inuit and First Nations populations. In the absence of coexisting human immunodeficiency virus infection and alcohol abuse, the outcomes of HBV and HCV appear to be more benign than in non-Aboriginal Canadians.

Key Words: Aboriginal; First Nations; Hepatitis; Hepatitis A; Hepatitis B; Hepatitis C; Inuit; Liver disease; Viral hepatitis

\section{Hépatite virale chez les Inuits et les Premières nations au Canada}

OBJECTIF : Passer en revue les données publiées sur la prévalence de l'hépatite A (HVA), de l'hépatite B (HVB) et de l'hépatite C (HVC) chez les Inuits et les Premières nations au Canada.

MÉTHODE : Recherche dans la base de données PubMed et examen de toutes les publications faisant état de données provenant d'enquêtes séroépidémiologiques.

RÉSULTATS : Premièrement, la prévalence de la séropositivité antiHVA déclarée jusqu'à maintenant chez les Inuits et les Premières nations au Canada est élevée $(75 \%-95 \%)$ et elle est à peu près trois fois supérieure à celle enregistrée chez les non-Autochtones dans les mêmes communautés. Deuxièmement, la prévalence de l'HVB chez les Inuits est d'environ $5 \%$, soit 20 fois celle relevée chez les Canadiens non autochtones, et le risque d'exposition au virus de l'hépatite B oscille autour de $25 \%$, soit un risque 5 fois plus élevé. Toutefois, d'après des données préliminaires, la prévalence de l'HVB (0,3\%-3\%) et l'exposition au virus $(10 \%-22 \%)$ chez les Premières nations et les Métis atteindraient des taux comparables à ceux notés chez les non-Autochtones demeurant dans les mêmes régions et participant au même genre d'activités très risquées. Troisièmement, les signes sérologiques d'infection au virus de l'hépatite C (anticorps anti-HVC) sont plus fréquents chez les Inuits ( $1 \%-18 \%$ ) que dans le reste de la population au Canada (0,5 \%-2 \%); par contre, les signes de virémie (positivité à l'égard de l'ARN du virus de l'hépatite C) sont moins fréquents (moins de $5 \%$ contre $75 \%$ de personnes séropositives anti-HVC, respectivement).

CONCLUSION : L'hépatite virale est fréquente chez les Inuits et les Premières nations au Canada mais, en l'absence d'infection par le virus de l'immunodéficience humaine et d'abus d'alcool concomitants, l'évolution de l'HVB et de l'HVC semble moins grave dans ces populations que chez les non-Autochtones.
$\mathrm{V}$ iral hepatitis is an inflammatory condition of the liver that can lead to death from fulminant hepatic failure, cirrhosis and/or hepatocellular carcinoma. Of the eight hepatotropic viruses discovered to date, hepatitis A (HAV), B (HBV) and C virus $(\mathrm{HCV})$ have been associated with the highest mortality rates in nonpregnant patients (1). Routes of transmission vary among the viruses. For example, HAV is largely spread by fecal contamination of food or drinking water, whereas HBV is most often spread by injection drug use in developed nations and maternal-infant transmission in developing nations (2). Sexual and intimate contact is thought to be a common route of HBV transmission in both developed and developing nations (2). HCV transmission is somewhat similar to that of
HBV in that it too is most commonly spread by injection drug use in developed nations but by nosocomial transmission in developing nations (2). Sexual transmission of HCV is less common than with HBV (2).

The Inuit and First Nation populations of Canada may be at increased risk for infection with each of these viruses for several reasons. As found repeatedly, poor health and social issues such as poverty, low education levels, limited housing and high unemployment amongst Aboriginal peoples may lead to sanitation problems and thereby, more frequent HAV transmission, as well as early or more regular involvement in certain high-risk activities resulting in more frequent $\mathrm{HBV}$ and $\mathrm{HCV}$ transmission (3). Moreover, the over representation of

Section of Hepatology, Department of Medicine, University of Manitoba, Winnipeg, Manitoba

Correspondence and reprints: Dr Gerald Y Minuk, Head, Section of Hepatology, University of Manitoba, John Buhler Research Centre, 803F-715 McDermot Avenue, Winnipeg, Manitoba R3E 3P4. Telephone 204-789-3204, fax 204-789-3971, e-mail gminuk@cc.umanitoba.ca 
Aboriginals amongst injection drug users and prison inmates (groups with high prevalences of $\mathrm{HBV}$ and $\mathrm{HCV}$ infection) represents a continuous source of infection amongst Aboriginal people. Finally, in the Inuit population, widespread bacille Calmette-Guérin injections have been administered for prophylaxis against tuberculosis for decades, the early phase of which may have involved the use of nondisposable equipment and, thereby, and increased risk of nosocomial transmission of HBV and/or HCV (4).

The purpose of the present paper is to review what is presently known about viral hepatitis in the Canadian Inuit and First Nations populations based on published data from the medical literature and as yet unpublished data generated by the authors.

\section{METHODS}

Electronic searches using PubMed/MEDLINE databases were conducted (April and November 2002) to identify and review all published prevalence/seroepidemiologic studies of HAV, HBV and $\mathrm{HCV}$ in Canadian Aboriginal populations. The search was conducted without language restrictions using the strategy indicated in Appendix A.

\section{HAV}

\section{RESULTS AND DISCUSSION}

The first published, population-based survey of the prevalence of antibody to HAV (anti-HAV) in the Inuit population of Canada was in 1982, when Minuk et al (5) reported the results of testing in 708 inhabitants (approximately $70 \%$ of the total population) of Baker Lake, Northwest Territories. Sera had been obtained in 1980 and tested for immunoglobulin (Ig) G anti-HAV using a solid phase radioimmunoassay. A total of $494(75 \%)$ of the Inuit residents were anti-HAV positive compared with eight of $48(17 \%)$ white residents in the same community. There were no significant differences in the prevalence of anti-HAV between the sexes but rates increased with age (Figure 1). Of the seven infants less than one year of age, three (all younger than six months of age) were IgG antiHAV positive but none IgM anti-HAV positive, suggesting transplacental transfer of maternal anti-HAV. For those between the ages of one and four years, the prevalence of antiHAV was low, then increased, such that by age seven years over $70 \%$ had serological evidence of HAV. Until the age of 40 years, the rate remained at approximately $75 \%$ but almost $100 \%$ of the older individuals in the community had serological evidence of past infection. None of the 90 anti-HAV positive serum samples tested for IgM anti-HAV was reactive.

The same study demonstrated a strong association $(\mathrm{P}<0.005)$ between the prevalence of anti-HAV and the number of individuals per house. In uncrowded houses (those with two or three occupants) only $64 \%$ of the inhabitants had antiHAV in their serum, whereas in houses with eight or more occupants $86 \%$ were positive. The highest rate was found in houses with only one occupant (87\%) but this apparent anomaly was likely related to the more advanced age of these individuals. A similar but not significant correlation between household size and anti-HAV prevalence was seen for the children of the community $(0.1<\mathrm{P}>0.05)$.

A second HAV study was performed by the same investigators in 1982 when 172 residents of the community of Chesterfield Inlet (estimated population at the time: 220) were tested for IgG anti-HAV (6). One hundred thirty-one
(76\%) individuals were seropositive. Only 30\% of the children below 10 years of age were anti-HAV positive. The prevalence of antibodies then rose sharply to $80 \%$ in the 10 - to 19 -yearolds and remained at levels greater than $85 \%$ in all older age groups (Figure 2).

More recently, data have been obtained from 293 (34\% of the total population) of two additional but anonymous Inuit communities. In these communities, $82 \%$ of samples were IgG anti-HAV positive (authors' unpublished data). Age and sex distributions are not available.

To date, there has been only one published report of the prevalence of anti-HAV in an urban First Nations/Metis population (7). That study, performed in 1995 to 1996, involved 553 street-involved individuals residing in Winnipeg, Manitoba (total number of street-involved individuals; unknown). Three hundred seventeen of the 553 participants identified themselves as First Nations or Metis. A total of 212 First Nation and 53 Metis samples were available for anti-HAV testing. In this nonrepresentative high risk subset of the First Nations and Metis population, 72\% of the 212 First Nations and $42 \%$ of the 53 Metis were IgG anti-HAV positive compared with $28 \%$ of 119 non-First Nations/Metis streetinvolved people (OR 5.0, 95\% CI 3.1-8.0, $\mathrm{P}<0.001$ ). Although the age distribution of the First Nation/Metis participants was not provided, the mean age of the entire study population was 25.7 years (range 11 to 65 years) and 53\% were female.

Data from a 1996 serosurvey of a First Nations reserve in Manitoba with a population of 1036 have revealed that $95 \%$ of 315 samples tested (117 males and 198 females, mean age $34.4 \pm 15.1$ years, range 1.5 to 82 years) were positive for IgG anti-HAV (8). The prevalence rate in males was similar to that of females (96\% versus 94\%, respectively).

Summary: The prevalence of anti-HAV positivity in all Canadian Inuit and First Nations populations reported to date is high (range $75 \%$ to $95 \%$ ) and approximately three times that of non-Aboriginals residing in the same communities (Table 1). These findings underscore the problems that exist with respect to sanitary conditions, personal hygiene and the safety of community food and water in Inuit and First Nations populations. They also emphasize the importance of HAV vaccination of susceptible adults in this segment of the Canadian population.

\section{$\mathrm{HBV}$ in the Inuit and First Nations populations}

The same study that described HAV in the Inuit population of Baker Lake was also the first to describe the prevalence of HBV infection in a Canadian Inuit population (9). Of the 720 samples tested, $36(5 \%)$ were hepatitis B surface antigen (HBsAg) positive and $27 \%$ had evidence of previous HBV exposure (either antibody to hepatitis B core antigen [anti-HBc] and/or antibody to HBsAg [anti-HBs] positive). Males were twice as likely to be HBsAg positive than females. None of the 49 white residents in this community was $\mathrm{HBs} \mathrm{Ag}$ positive, and serological evidence of previous HBV exposure was present in only $5 \%$. Recent genotyping of the HBV genome revealed genotypes B (in keeping with an Asian rather than North American source) or mixed A/B, subtype adw, in all cases (10).

The age at which Inuit in the community became infected was unclear. $\mathrm{HBs} \mathrm{Ag}$ persistence rates reflect the age of HBV exposure. They are calculated by dividing the number of HBsAg-positive individuals by the number of individuals with 


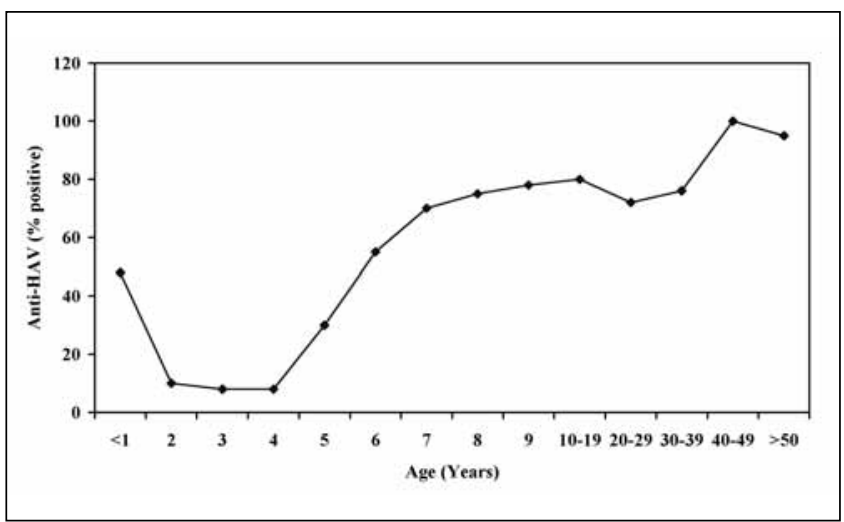

Figure 1) Age-specific prevalence rates for antibody to hepatitis A virus (anti-HAV) in 708 inhabitants of Baker Lake, Northwest Territories, 1980. Data from reference 5

any positive HBV marker. In this community the persistence rate was $15 \%$, suggesting individuals tended to be infected at birth or during early childhood. However, age-specific prevalence rates revealed no carriers under the age of 20 years and relatively low rates of HBV exposure until early adulthood and beyond (Figure 3). Also in keeping with limited neonatal and childhood exposure were the results of hepatitis B early antigen ( $\mathrm{HBe} \mathrm{Ag}$ ) and antibody to $\mathrm{HBeAg}$ (anti-HBe) testing, wherein high $\mathrm{HBeAg}$-positive rates are predicted in populations where infection occurs early in life. In the $36 \mathrm{HBsAg}$ positive carriers identified, none was $\mathrm{HBeAg}$ positive and 34 were anti-HBe positive.

In addition to the unusual serological pattern described above, biochemical evidence of active liver disease was surprisingly rare. Indeed, no HBV carrier had elevated liver enzymes or abnormal liver function tests. Alpha-fetoprotein levels, which are elevated in $60 \%$ to $80 \%$ of patients with hepatocellular carcinoma, were within the normal range in all cases. Recently, $38 \mathrm{HBs} \mathrm{Ag}$-positive carriers from the region were further studied for evidence of HBV mutations (11). A large percentage $(80 \%)$ were positive for the precore mutation, the highest prevalence reported to date but negative for the basic core promoter mutations (nt 1762/1764), often associated with more active disease (12).

Subsequent studies by Larke et al (13) in the Northwest Territories, Baikie et al (14) in Northern Labrador and Minuk et al (6) in an additional Inuit community support the results of the initial Minuk study (9). Specifically, in the Larke et al (13) study (Table 2), of 14,198 residents of the Yukon and Northwest Territories $(30 \%$ of the total population in the region at the time), $3 \%$ were $\mathrm{HBs} A g$-positive and $21 \%$ had serological evidence of previous HBV exposure (anti-HBs) before the introduction of HBV vaccination in 1988. Rates in the Inuit ( $4 \%$ and $25 \%$ ) were similar to those in the Dene population (3\% and 22\%) and higher than in whites residing in the region $(0.3 \%$ and $8.5 \%$, respectively). Of note, Larke and colleagues (13) found a higher prevalence of $\mathrm{HBeAg}$ positivity $(8.8 \%)$ than was the case in the Minuk studies $(0 \%)(6,9)$. In the Baikie et al (14) study of 2156 inhabitants of Northern Labrador (62\% of the total population), 3.2\% were $\mathrm{HBsAg}$ positive and $14.7 \%$ had evidence of previous HBV exposure. Once again, the HBsAg carrier and HBV exposure rates were significantly higher in the Inuit (6.9\% and $26.4 \%$, respectively) than in whites $(0 \%$ and $2.5 \%$, respectively). As in the Minuk

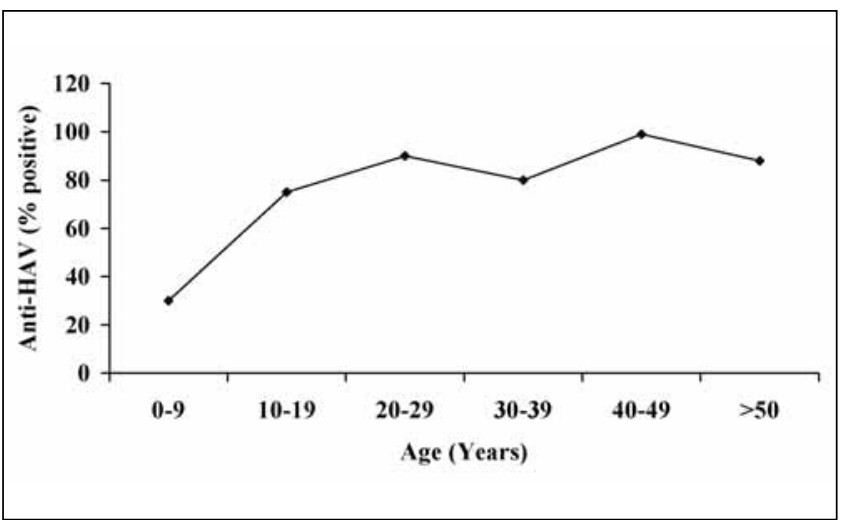

Figure 2) Age-specific prevalence rates for antibody to hepatitis A virus (anti-HAV) in 172 inhabitants of Chesterfield Inlet, Northwest Territories, 1982. Data from reference 6

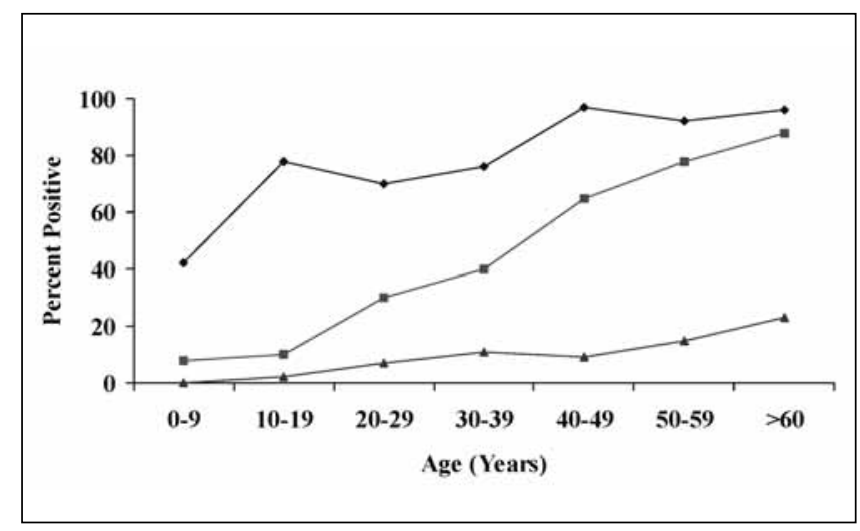

Figure 3) Age-specific prevalence rates for antibody to hepatitis A virus (anti-HAV), any hepatitis B marker (HBV) and hepatitis B surface antigen (HBsAg) in 708 (HAV) and 720 (HBV) inhabitants of Baker Lake, Northwest Territories, 1980. Data from reference 9

studies, Baikie et al (14) did not find HBeAg positivity in their HBsAg-positive carriers and also described a low prevalence of HBV exposure (4\%) in individuals under the age of 20 years.

Of 190 samples tested from the two anonymous Inuit communities referred to above, 21 (11\%) were anti-HBc-positive and of these, four were $\mathrm{HBs} \mathrm{Ag}$-positive and $17 \mathrm{HBs} \mathrm{Ag}$-negative. Thus, the overall prevalence of $\mathrm{HBs} A g$ infection in these two communities was approximately $2 \%$. Once again, age and sex data are not available for the inhabitants of these two communities.

Regarding the First Nations population, as mentioned earlier, Larke et al (13) documented an HBsAg prevalence rate of 3\% and exposure rate of $22 \%$ in the Dene population of the Northwest Territories. In the more recent study of the Manitoba First Nation reserve community, Minuk et al (8) found seven of 301 samples tested (2.3\%) were anti-HBc positive and none $\mathrm{HBs} \mathrm{Ag}$ positive. Of those that were anti-HBc positive, six were male and one was female. All but one of the anti-HBc positive individuals were over the age of 20 years, but none were over 60 years.

In British Columbia, 2166 attendees at a First Nations Alcohol and Drug Treatment centre were tested for HBV markers between the years 1992 and 2000 (15). Of these, 
TABLE 1

Viral hepatitis in Canadian Inuit and First Nations populations community-based prevalence studies

\begin{tabular}{|c|c|c|c|c|c|}
\hline Virus & Study year & Subjects (n) & Ethnicity & Prevalence (\%) & Investigator \\
\hline \multirow[t]{8}{*}{ Hepatitis A } & 1980 & 494 & Inuit & 75 & Minuk et al $1982(9)$ \\
\hline & & 48 & White & 17 & \\
\hline & 1983 & 172 & Inuit & 76 & Minuk et al 1985 (6) \\
\hline & 2000 & 293 & Inuit & 82 & Minuk et al (unpublished) \\
\hline & 1995-1996 & 212 & First Nations & 72 & Moses et al $2002(7)$ \\
\hline & & 53 & Metis & 42 & \\
\hline & & 119 & Non-Aboriginal & 28 & \\
\hline & 2000 & 315 & First Nations & 95 & Minuk et al 2003 (8) \\
\hline \multirow[t]{11}{*}{ Hepatitis $\mathrm{B}^{*}$} & 1980 & 720 & Inuit & $4 / 27$ & Minuk et al 1982 (9) \\
\hline & 1983-1985 & 8282 & Inuit & $4 / 25$ & Larke et al 1986 (13) \\
\hline & & 3140 & Dene & $3 / 22$ & \\
\hline & & 2776 & Non-Aboriginal & $0.3 / 9$ & \\
\hline & & 2156 & Inuit & $7 / 26$ & Baikie et al (14) \\
\hline & & & White & $0 / 3$ & \\
\hline & 2000 & 190 & Inuit & $2 / 11$ & Minuk et al (unpublished) \\
\hline & 1995-1996 & 217 & First Nations & $2 / 10$ & Moses et al $2002(7)$ \\
\hline & & 53 & Metis & $2 / 12$ & \\
\hline & & 134 & Non-Aboriginal & $5 / 9$ & \\
\hline & 1992 & 2166 & First Nations & $0.3 / 10$ & Martin et al 2002 (15) \\
\hline \multirow[t]{7}{*}{ Hepatitis C } & 1980 & 720 & Inuit & $0.3 / 1.0^{\dagger}$ & Minuk et al 1991 (16) \\
\hline & 2000 & 190 & Inuit & 18 & Minuk et al (unpublished) \\
\hline & Unknown & Unknown & $92 \%$ First Nations & 41 & Prince Albert Seroprevalence Study (17) \\
\hline & 1995-1996 & 217 & First Nations & 19 & Moses et al 2002 (7) \\
\hline & & 53 & Metis & 22 & \\
\hline & & 134 & Non-Aboriginal & 14 & \\
\hline & 2000 & 315 & First Nations & 2 & Minuk et al 2003 (8) \\
\hline
\end{tabular}

*Indicates infected/exposed; †Indicates initial/retested result

TABLE 2

Distribution of Hepatitis B virus (HBV) serological markers by geographic region and ethnic group, Northwest Territories, 1983 to $1985^{*}$

\begin{tabular}{|c|c|c|c|c|c|c|c|}
\hline \multirow[b]{2}{*}{ Marker } & \multirow[b]{2}{*}{ Group } & \multirow[b]{2}{*}{ Baffin (12) } & \multicolumn{3}{|c|}{ Region (number of communities surveyed) } & \multirow[b]{2}{*}{ Fort Smith (15) } & \multirow[b]{2}{*}{ Total (51) } \\
\hline & & & Keewatin (8) & Kitikmeot (6) & Inuvik (10) & & \\
\hline HBsAg & Inuit & $164 / 2990(5.5)$ & $94 / 2810(3.3)$ & $62 / 1602(3.9)$ & $7 / 774(0.9)$ & $0 / 106(0.0)$ & $327 / 8282(3.9)$ \\
\hline $\mathrm{HBsAg}$ & Dene & NT & $0 / 6(0.0)$ & NT & $15 / 1082(1.4)$ & $77 / 2052(3.8)$ & $92 / 3140(2.9)$ \\
\hline $\mathrm{HBsAg}$ & Other & $4 / 277(1.4)$ & 2/198 (1.0) & $0 / 113(0.0)$ & $2 / 770(0.3)$ & $1 / 1418(0.07)$ & $9 / 2776(0.3)$ \\
\hline HBsAg & All & $168 / 3267(5.1)$ & $96 / 3014(3.2)$ & $62 / 1715(3.6)$ & $24 / 2626(0.9)$ & $78 / 3576(2.2)$ & $428 / 14,198(3.0)$ \\
\hline Anti-HBs & Inuit & $993 / 2990(33.2)$ & $627 / 2810(22.3)$ & $318 / 1602$ (19.9) & $71 / 774(9.2)$ & 22/106 (20.8) & $2031 / 8282(24.5)$ \\
\hline Anti-HBs & Dene & NT & $0 / 6(0.0)$ & NT & $145 / 1082(13.4)$ & $531 / 2052(25.9)$ & $676 / 3140(21.5)$ \\
\hline Anti-HBs & Other & $15 / 277(5.4)$ & $18 / 198(9.1)$ & $10 / 113(8.8)$ & $62 / 770(8.1)$ & $131 / 1418(9.2)$ & $236 / 2776(8.5)$ \\
\hline Anti-HBs & All & $1008 / 3267(30.9)$ & $645 / 3014(21.4)$ & $328 / 1715$ (19.1) & $278 / 2626(10.6)$ & $684 / 3576(19.1)$ & $2943 / 14198(20.7)$ \\
\hline $\mathrm{HBeAg}$ & All & 14/167 (8.4) & $4 / 96(4.2)$ & $1 / 59(1.7)$ & $1 / 22(4.5)$ & 17/77 (22.1) & $37 / 421(8.8)$ \\
\hline $\mathrm{HBsAg}$ or anti-HBs ${ }^{\dagger}$ & All & $1177 / 3267(36.0)$ & $741 / 3014(24.6)$ & $390 / 1715(22.7)$ & $302 / 2626(11.5)$ & $762 / 3576(21.3)$ & $3372 / 14198(23.7)$ \\
\hline $\mathrm{HbsAg}$ and anti-HBs ${ }^{\ddagger}$ & All & 69/168 (41.1) & 27/96 (28.1) & 25/62 (40.3) & $8 / 24(33.3)$ & $24 / 78(30.8)$ & $153 / 428(35.7)$ \\
\hline HBsAg range§ (\%) & All & $0.4-11.7$ & $1.1-9.4$ & $2.0-5.6$ & $0-4.9$ & $0-11.7$ & $0-11.7$ \\
\hline Anti-HBs range ${ }^{\S}(\%)$ & All & $14.8-51.7$ & $7.5-40.9$ & $12.9-24.3$ & $4.1-17.2$ & $4.2-53.3$ & $4.1-53.3$ \\
\hline
\end{tabular}

${ }^{*}$ Results are number positive/total number (\%); †Persons with any marker of HBV infection (hepatitis B surface antigen [HBsAg] or antibody to hepatitis B surface antigen [anti-HBs]); $¥$ Persons with both HBsAg and anti-HBs in the same serum sample; §Range of prevalence rates of HBV marker among the number of communities in the region. HBeAg Hepatitis B early antigen; NT None tested. Data from reference 13

seven (0.3\%) were HBsAg-positive, 196 (10.2\%) anti-HBcpositive and 503 (23\%) anti-HBs-positive; the higher rate of anti-HBs positivity (which had increased from 7\% in 1992 to $42 \%$ in 2000) presumably reflected active immunization in this population.

The Winnipeg Viral Hepatitis Street-Involved Youth study (7) provides the only additional published data regarding HBV infection amongst an urban, First Nation/Metis population. In this high risk group, a total of 270 samples (217 First Nations and 53 Metis) were available for HBV testing. Amongst the
First Nations, five (2.3\%) were HBsAg positive and 21 (9.7\%) anti-HBs positive. Amongst the Metis, one (1.9\%) individual was positive for HBsAg and six (11.3\%) positive for anti-HBs. These findings were not significantly different from the 134 non-Aboriginal street involved people where the prevalence of HBsAg positivity was $4.5 \%$ and anti-HBs positivity $9.0 \%$.

Summary: Amongst the Canadian Inuit, the prevalence of $\mathrm{HBV}$ infection is approximately $5 \%$ or 20 times that of whites living in southern Canada, while the risk of exposure to HBV is $25 \%$ or five times higher (Table 1). Limited data suggest 
the prevalence of precore mutant infections is particularly high but active disease uncommon in the Canadian Inuit population. Regarding the First Nations/Metis population, preliminary data indicate the prevalences of HBV infection $(0.3 \%$ to $3 \%)$ and exposure $(10 \%$ to $22 \%)$ are similar to rates in non-First Nations/Metis residing in the same regions/areas and participating in similar high risk activities. There are insufficient data to determine the replicative activity and/or clinical outcomes of acute or chronic HBV infection in this population.

\section{$\mathrm{HCV}$ in the Inuit and First Nations populations}

To date, the only published report describing the prevalence of $\mathrm{HCV}$ infection in a Canadian Inuit population was from Baker Lake, Northwest Territories (16). Using a first generation antibody to HCV (anti-HCV) assay only two of $720(0.3 \%)$ sera tested positive. A recent reanalysis of 468 of the same sera using a third generation enzyme immunoassay (EIA) increased the number of positive results to five (1.1\%) (authors' unpublished data). Of note, HCV-RNA testing by polymerase chain reaction (PCR) in each of these samples was negative. The ages of the anti-HCV positive individuals were eight, nine, 15, 49 and 50 years, suggesting that some nonparenteral transmission may be occurring in this population.

In the two anonymous Inuit communities referred to earlier, 29 of $190(15 \%)$ were anti-HCV positive by third generation EIA but only one was HCV-RNA positive by PCR despite careful and appropriate sample preparation and the use of sensitive HCV-RNA testing (sensitivity 100 copies $/ \mathrm{mL}$ ).

Regarding First Nations populations, in the Winnipeg Viral Hepatitis Street Involved Youth study (7) the anti-HCV prevalence amongst self-identified Aboriginal youth was 20\%, and $14 \%$ amongst those of non-Aboriginal ethnicity $(\mathrm{P}=0.17)$. When further analyzed, evidence of $\mathrm{HCV}$ infection was present in $22 \%$ of self-identified Metis and $19 \%$ of selfidentified First Nations participants. Of note, 33\% of Aboriginals in this study reported injection drug use compared with $22 \%$ of the non-Aboriginals; however, this difference was not significant (7).

The survey of the Manitoba First Nations reserve community discussed above documented an anti-HCV prevalence of $2.2 \%$ but an HCV-RNA (by reverse transcription-PCR) positive rate of less than $0.1 \%$ (8). Similarly, a review of 1881 results of anti-HCV and HCV-RNA testing in Manitoba between the years 1996 and 1999 revealed higher rates of HCV-RNA negativity amongst 188 anti-HCV-positive First Nations people (32.6\%) compared with the 1693 remaining anti-HCV-positive non-First Nations Manitobans (22.6\%) $(\mathrm{P}<0.05)$. The reason for this finding (anti-HCV positive, HCV-RNA negative) remains unclear. Possibilities include an enhanced immune response to HCV infection, and acquisition of the virus earlier in life (which is known to result in more efficient and frequent viral clearance) amongst Aboriginals.

Thus, in Manitoba, the prevalence of anti-HCV in the First Nations population is approximately $1.5 \%$ compared with $0.5 \%$ for non-Aboriginal Manitobans, but persistent viral infection appears to be less common in the Aboriginal population.

In Saskatchewan, the results of a Prince Albert Seroprevalence Study (PASS) (unpublished data), conducted in the community and provincial correctional facilities, revealed the prevalence of anti-HCV amongst 188 injection drug users to be $50 \%$. The total prevalence was $41 \%$, and $92 \%$ of the study population were aboriginal people. HCV-RNA testing was not performed.

In British Columbia, a large study (18) of HCV infection amongst 1345 injection drug users during an human immunodeficiency virus outbreak provided data on $\mathrm{HCV}$ incidence and prevalence amongst the Aboriginal injection drug user population. The overall prevalence of anti-HCV at enrollment in this study was $82 \%$. Forty per cent of initially seronegative participants acquired $\mathrm{HCV}$ during the 16 months of follow-up. Seroconversion was slightly more frequent amongst Aboriginal drug users (53\%) than whites (43\%), and significantly more frequent than amongst individuals of other ethnic backgrounds (26\%) (18). In a smaller study from the same province, the prevalence of anti-HCV was $18 \%$ amongst 412 attendees of a First Nations alcohol and drug rehabilitation program (19).

Regarding the course of HCV infection in Inuit and First Nations populations, alcohol abuse is a highly prevalent problem in this population and a significant factor predisposing to the development of cirrhosis in $\mathrm{HCV}$-infected individuals (20). In the PASS study, $65 \%$ of the study population had a history of alcohol abuse in addition to injection drug use. Steatosis is another risk factor associated with more active and progressive disease (21). Because approximately $50 \%$ of diabetics have fatty livers, one might expect higher rates of progression and/or more complications in HCV-infected diabetic patients. Given that the prevalence of diabetes amongst First Nations peoples is at least three times higher than amongst non-First Nations peoples, here again, one might predict more advanced liver disease and complications thereof in the First Nations population (22). Therefore, a more rapid progression of HCV infection could be expected in those Aboriginals who remain chronically infected with HCV.

Summary: To date, available data suggest that serological evidence of HCV infection is more common in the Canadian Inuit ( $1 \%$ to $18 \%)$ than in the remainder of the Canadian population ( $0.5 \%$ to $2 \%)$; however, viremia is less common (Table 1$)$. In terms of the First Nation population, preliminary data indicate the same findings apply to this population (high serological evidence of HCV infection but lower than predicted rates of viremia). Together, these findings suggest that while infection rates are high, the Canadian Inuit and First Nation populations may have an increased ability to clear the virus once infected. In those who fail to clear the virus, coexisting alcohol abuse and diabetes may increase the risk of progression to cirrhosis and/or hepatocellular carcinoma.

\section{Limitations}

Although extensive efforts were undertaken to identify all relevant publications for this review, it is conceivable that additional MeSH headings may have provided additional relevant papers. It is also possible that relevant articles published in journals not included in MEDLINE, books, monographs and conference proceedings were missed. Finally, the omission of yet unpublished manuscripts and data could not be avoided.

An additional limitation (perhaps of the issue rather than the review) was the inability to provide evidence-based suggestions regarding the value and efficacy of immunoprophylaxis and preventative measures in this population. Such suggestions require a better understanding of the modes and ages of viral transmission, information that in this population remains largely speculative. 
ACKNOWLEDGEMENTS: This review was commissioned by the Blood Borne Pathogens Division, Health Canada, Ottawa, Ontario. Some of the data and portions of the review have appeared in previous publications by the authors. The authors thank Mrs S Zdanuk for her prompt and accurate typing of the report.

\section{APPENDIX A}

Search criteria used in the electronic searches of the PubMed/MEDLINE databases: ("Hepatitis A" [MeSH] OR "hepatitis A, epidemiology" [MeSH] OR "hepatitis A, ethnology" [MeSH] OR "HAV" OR "hepatitis A" OR "Hepatitis B" [MeSH] OR "hepatitis B, Chronic" [MeSH] OR "hepatitis B, epidemiology" [MeSH] OR "hepatitis B, ethnology" [MeSH] OR "hepatitis B, Chronic, complications" [MeSH] OR "HBV" OR "hepatitis B" OR "Hepatitis C" [MeSH] OR "hepatitis C, Chronic" [MeSH] OR "hepatitis C, epidemiology [MeSH] OR hepatitis C, ethnology" [MeSH] OR "hepatitis C, Chronic, complications" [MeSH] OR "HCV" OR "hepatitis C" OR "Hepatitis antibodies [MeSH] OR "Hepatitis B antibodies [MeSH]) OR "Hepatitis C antibodies" [MeSH] OR "Hepatitis antigens [MeSH] OR "Hepatitis B Antigens" [MeSH] OR "Hepatitis B Core Antigens" [MeSH] OR "Hepatitis B e Antigens" [MeSH] OR "Hepatitis B Surface Antigens" [MeSH] OR "Hepatitis C Antigens" [MeSH]) AND (aborigines [MeSH] OR Eskimos [MeSH] OR "Indians, North American" [MeSH] OR Eskimo OR Inuit OR "Native American" OR "first nations" OR Dene OR Metis OR "aboriginal peoples" OR "status Indians" OR "Non-status Indians" OR "treaty Indians") AND (seroepidemiologic studies [MeSH] OR "population, surveillance" [MeSH] OR seroepidemiolog*).

\section{REFERENCES}

1. Purcell RH. The discovery of the hepatitis viruses. Gastroenterology 1993;104:955-63.

2. Poovorawan Y, Chatchatee P, Chongsrisawat V. Epidemiology and prophylaxis of viral hepatitis: A global perspective. J Gastroenterol Hepatol 2002;17:S155-66.

3. Albrecht CE. Circumpolar Health: Present and Future. Circumpolar Health University of Washington Press, Seattle and London 1984;84:36-9.

4. Young TK. BCG vaccination among Canadian Indians and Inuit: The epidemiological bases for policy decision. Can J Public Health 1985;76:124-9.
5. Minuk GY, Waggoner JG, Jernigan R, Nicolle LE, Postl B, Hoofnagle JH. Prevalence of antibody to hepatitis A virus in a Canadian Inuit community. CMAJ 1982;127:850-2.

6. Minuk GY, Ling N, Postl B, Waggoner JG, Nicolle LE, Hoofnagle JH. The changing epidemiology of hepatitis B virus infection in the Canadian north. Am J Epidemiol 1985;121:598-604.

7. Moses S, Mestery K, Kaita KDE, Minuk GY. Viral hepatitis in a Canadian street-involved population. Can J Public Health 2002;93:123-8.

8. Minuk GY, Zhang M, Wong SGM, et al. Viral hepatitis in a Canadian First Nations community. Can J Gastroenterol 2003;17:593-6.

9. Minuk GY, Nicolle LE, Postl B, Waggoner JG, Hoofnagle JH. Hepatitis virus infection in an isolated Canadian Inuit (Eskimo) population. J Med Virol 1982;10:255-64.

10. Zhang M, Gong Y, Osiowy C, Minuk GY. Rapid detection of hepatitis B virus mutations using real-time PCR and melting curve analysis. Hepatology 2002;36:723-38.

11. Minuk GY, Orr PS, Brown R, Macdonald S, Chaudhary RK, Temple P. Pre-core mutant infections in the Canadian Inuit. J Hepatol 2000;33:781-4.

12. Minuk GY. Hepatitis B viral mutants and their relevance to the Canadian health care system. Can J Gastroenterol 2002;16:45-54.

13. Larke RPB, Froese GJ, Devine RDO, Petruk MW. Extension of the epidemiology of hepatitis $\mathrm{B}$ in circumpolar regions through a comprehensive serologic study in the Northwest Territories of Canada. J Med Virol 1987;22:269-76.

14. Baikie M, Ratnam S, Bryant DG, Jong M, Bokhout M. Epidemiologic features of hepatitis B virus infection in Northern Labrador. CMAJ 1989;141:791-5.

15. Martin JD, Mathias RG, Sarin C, Byrne SE. HIV and hepatitis B surveillance in first nations alcohol and drug treatment centres in British Columbia, Canada 1992-2000. Int J Circumpolar Health 2002;61:104-9.

16. Minuk GY, Nicolle LE, Gauthier T, Brunka J. Prevalence of antibody to hepatitis $\mathrm{C}$ virus in an isolated Canadian Inuit settlement. Can J Infect Dis 1991;2:71-3.

17. Siushansian J, Vooght M, Archibald CP, et al. The Prince Albert Seroprevalence Study (PASS), 02/1996-05/1997 (unpublished).

18. Patrick DM, Tyndall MW, Cornelisse PGA, et al. Incidence of hepatitis $\mathrm{C}$ virus infection among injection drug users during an outbreak of HIV infection. CMAJ 2001;165:889-95.

19. Riben P, Bailey G, Hudson S, McCulloch K, Dignan T, Martin D. Hepatitis C in Canada's First Nations and Inuit populations: An unknown burden. Can J Public Health 2000;91(Suppl 1):S16-7.

20. Corrao G, Arico S. Independent and combined action of hepatitis $\mathrm{C}$ virus infection and alcohol consumption on the risk of symptomatic liver cirrhosis. Hepatology 1998;27:914-9.

21. Adinolfi LE, Gambardella M, Andreanna A, Tripodi MF, Utili R, Ruggiero G. Steatosis accelerates the progression of liver damage of chronic hepatitis $\mathrm{C}$ patients and correlates with specific HCV genotype and visceral obesity. Hepatology 2001;33:1358-64.

22. Young TK. Undiagnosed diabetes: Burden and significance in the Canadian population. Adv Exp Med Biol 2001;498:7-10. 


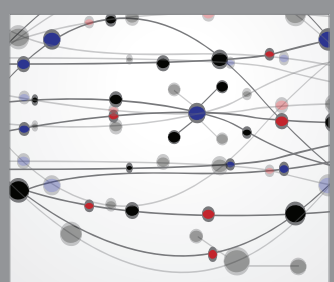

The Scientific World Journal
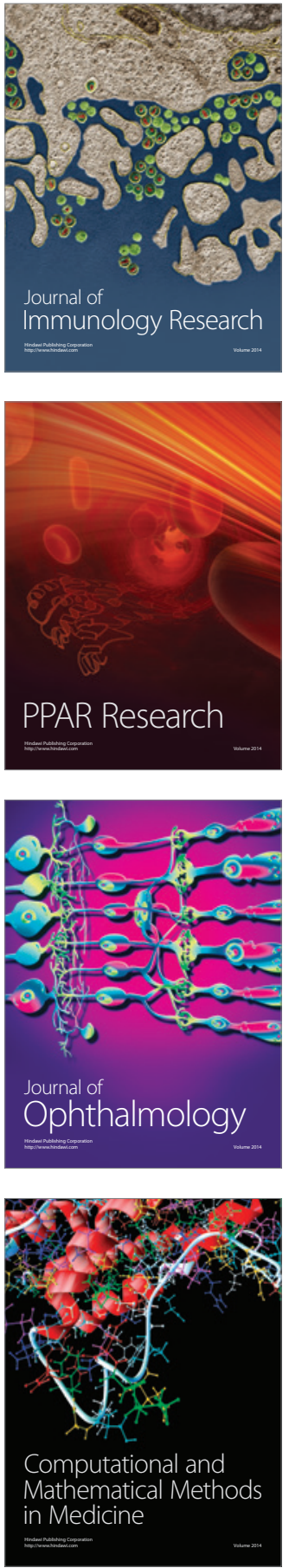

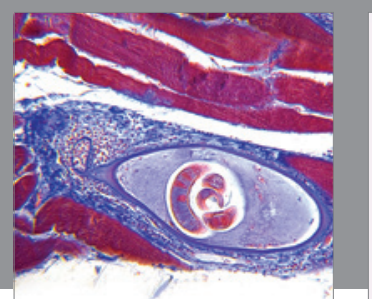

Gastroenterology Research and Practice

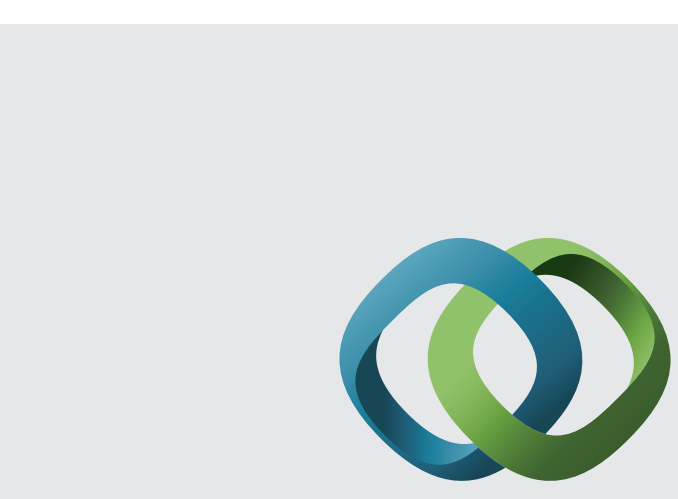

\section{Hindawi}

Submit your manuscripts at

http://www.hindawi.com
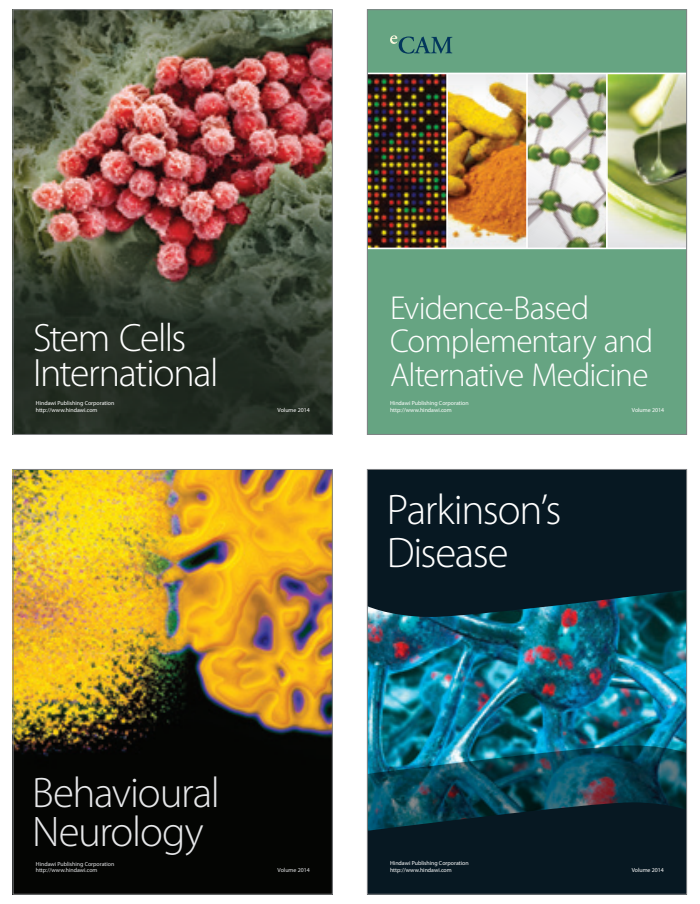
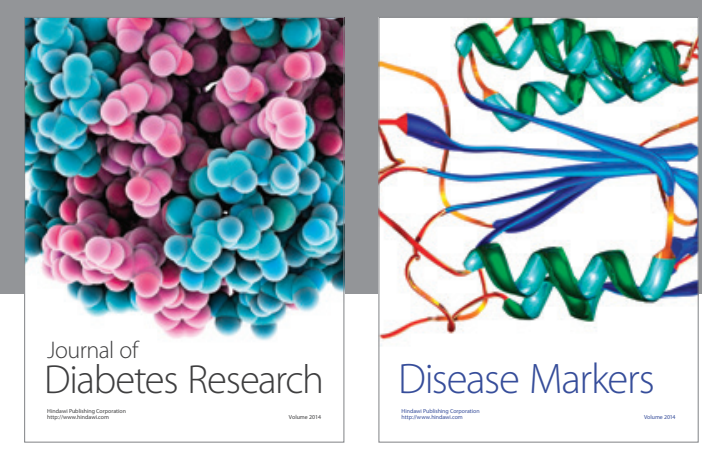

Disease Markers
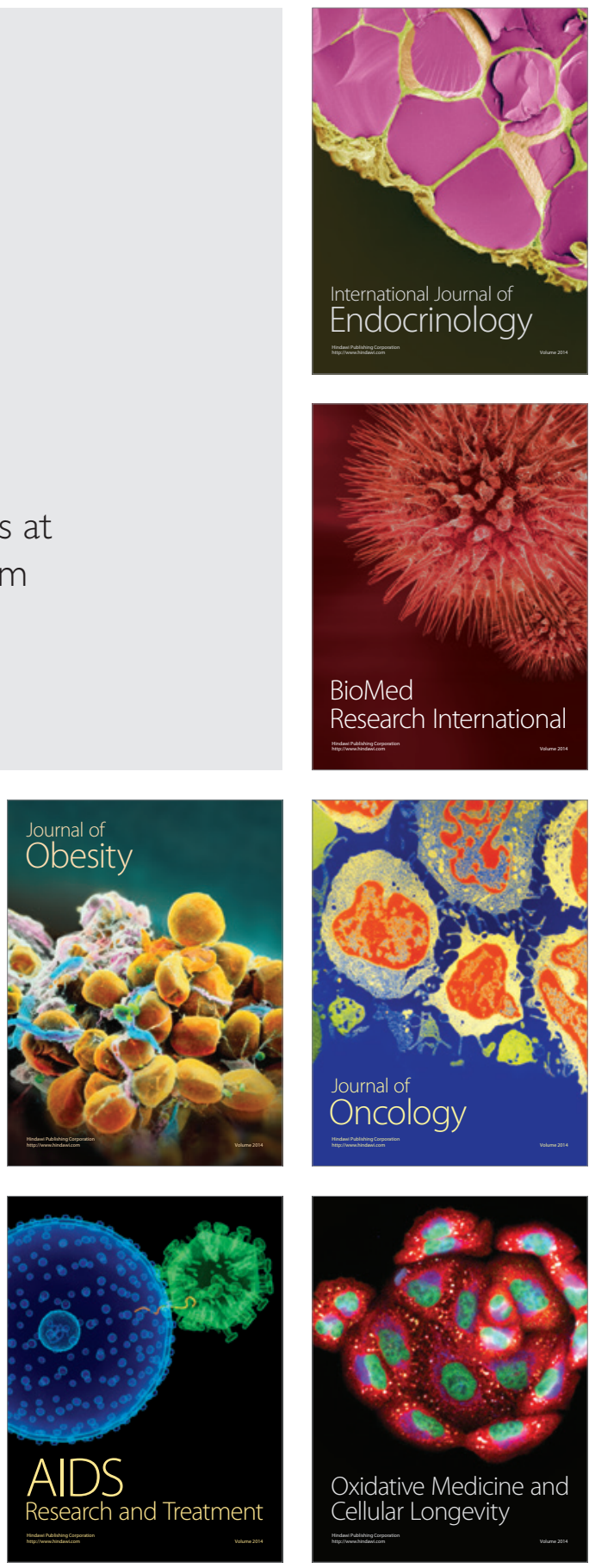